\title{
Mizantrop Bir Auteur : Zeki Demirkubuz
}

\author{
Eşref Akmeşe*
}

\section{Özet}

Insanlardan nefret eden veya insanlarn sevmeyen kimseler mizantrop, insanlardan nefret etme durumu ise mizantropi olarak tanımlanmaktadır. İnsanliğın doğasına ve eylemlerine karşı nefretin ifadesi olan mizantropi sadist bir eğilim olan başkalarına acı çektirmek, başkalarının act çektiklerini görmek, onları aşă̆glamak ve zayıflıklarını ifşa etmek isteği ile ilişkilidir. İnsanın ontolojik olarak kötü olduğu düşüncesini temel alan ve bu eksende filmlerinde "bireylere" act çektiren, insanlar utanç verici hallere düşüren, onları alçaltan Zeki Demirkubuz'un sinema anlayışı bu çerçevede anlam kazanmaktadır. Auteur yönetmenler kategorisinde değerlendirilen Demirkubuz, çeyrek asrn aşan sinema kariyerinde C Blok (1994), Masumiyet (1997), Üçüncü Sayfa (1999), Yazgı (2001), İtiraf (2002), Bekleme Odası (2003), Kader (2006), Kıskanmak (2009), Yeraltı (2012), Bulantı (2015) ve Kor (2016) adl filmlere imza atmıştır. Demirkubuz'un filmlerinde erkek "karakterler" için alçalmanın stnır yoktur ve aşă̆glanmalar süreklilik gösterir. Kadın "karakterler" ise femme fatale olarak kurgulanır ve mizojinin dışavurumu için araçsallaştırılır. Demirkubuz'un filmlerinde acı, aldatma, alçalma, aşağılanma, bunalım, hınç, sevgisizlik, sözlü şiddet, fiziksel şiddet ve kötülük konuları sürekli işlenmektedir. Albert Camus, Fyodor M. Dostoyevski, Jean-Paul Sartre gibi Varoluşçu isimlerin eserlerini "uyarlayan" Demirkubuz, yazılı felsefede tartışılan, nihilizm, kötülük, yazgı, bunaltı ve saçma gibi konuları filmlerinde odağa alma iddiası taşımakta ancak asıl olarak insana yönelik mizantropik tutumunu hareket-zaman bloklarndan oluşan sinema ile dışavurmaktadır. Her artistik imajın yaratıcısının düşüncelerini yansıttığı ve her sanatçının yarattığ düşünülemeyeceği gerçeğinin benimsendiği bu çalışmada Demirkubuz'un insan anlayışı, filmlerindeki asal motifler üzerinden mizantropi kavramı bağlamında tartışılmaya açılacaktır

Anahtar Kelimeler : Mizantropi, Mizantropist, Mizojini, İnsan, Zeki Demirkubuz

*ORCID: 0000-0003-0906-8928

E-Mail: esrefakmese@gmail.com

DOI: $10.31122 /$ sinefilozofi.674970

Geliş Tarihi - Recieved: 15.01.2020

Kabul Tarihi - Accepted: 10.05.2020 


\title{
A Misanthrope Auteur: Zeki Demirkubuz
}

\author{
Eşref Akmeşe*
}

\begin{abstract}
A person who hates or dislikes human beings is defined as a misanthrope and the case of hatred felt towards human beings is called as misanthropy. The misanthropy which is the expression of hatred towards the nature and actions of humankind pertains, as a sadistic inclination, to the willingness to inflict pain on others, to see them suffer from pain, to humiliate them and to reveal their weaknesses. Based on the idea that the human being is ontologically ill-mannered, and, on the basis of this idea, inflicting pain on 'individuals', putting them in humiliating circumstances and demeaning them, Zeki Demirkubuz's understanding of cinema gains its meaning in his films in this framework. Demirkubuz who is appraised in the category of film auteur put his signature on films named Block C (1994), Innocence (1997), Third Page (1999), Fate: Tales About Darkness (2001), The Confession: Tales About Darkness II (2002), The Waiting Room (2003), Destiny (2006), Envy (2009), Inside (2012), Nausea (2015) and Ember (2016) in his cinema career which extended beyond a quarter of a century. There is no limit on the self-abasement for male 'characters' and their debasement persists throughout films by Demirkubuz. On the other hand, female 'characters' are configured as femme fatale and they are used to act as instruments for the expression of misogyny. The pain, deception, debasement, humiliation, depression, grudge, lovelessness, verbal violence, physical violence and mischief persistently dominate films by Demirkubuz. Demirkubuz who 'adapts' works by Existentialist figures such as Albert Camus, Fyodor M. Dostoyevsky and Jean-Paul Sartre is alleged to place the focus on topics such as the nihilism, evil, fate, depression and absurdity in his films, however, he actually expresses his misanthropic attitude towards the human being through cinema which is comprised of blocks of motion $\mathcal{E}$ time. In this study which adopts the fact that each artistic image reflects its creator's ideas and each artist cannot be considered individually in separation from images he/she creates, Demirkubuz's understanding of human being will be brought up for discussion through basic motives in the context of misanthropy concept.
\end{abstract}

Key Words: Misanthropy, Misanthropist, Misogyny, Human Being, Zeki Demirkubuz

*ORCID: 0000-0003-0906-8928

E-Mail: esrefakmese@gmail.com

DOI: $10.31122 /$ sinefilozofi.674970

Received - Geliş Tarihi: 15.01.2020

Accepted - Kabul Tarihi: 10.05.2020 


\section{Giriş}

Günümüzde küresel düzeyde yaşanan krizler insanlığın geleceği açısından karamsar görüşleri beslemektedir. İnsanlığın içinde bulunduğu kötücül anafor evrensel düzeyde birçok insanı umutsuzluğa sürükleyen ciddi sonuçlara yol açmaktadır. Bu durum kötülüğün insan doğasında mutlak biçimde var olan ve aşılamayacak bir olgu olduğu izlenimini kimi insanlarda kolayca uyandırmaktadır. Söz konusu izlenimle oluşan yaklaşım yaşamın birçok alanında dile getirilmekte ve insan realitesi hakkında egemen bir görüş haline gelme potansiyeli taşımaktadır.

Kitlesel bir sanat olan sinema kendine özgü yapısı ve etkili anlatım olanaklarıyla hayatın yansıtılması ve insanı anlatmanın en etkili yolu olarak görülmektedir. Etkili bir düşünce üretme ve yayma mecrası olan sinema, belirtilen özellikleriyle izlerkitle üzerinde farklı boyutlarda sonuçlar doğurma potansiyeli içermektedir. Bu doğrultuda filmlere yansıyan düşüncelerin niteliğinin yaşam karşıtı mı yoksa yaşamdan taraf mı olduğu ya da insanı yüceltici mi alçaltıcı mı olduğunun irdelenmesi önem taşımaktadır. Bu kapsamda insanın geleceği için olumsuz görüşler taşıyan ve bu görüşleri sinemasal üretime dönüştüren yönetmenler, insana güvenmeyerek ve insanın potansiyelini küçümseyerek yaşam karşıtı bir konumda yer almaktadır. Bu çerçevede insana yönelik kötücül düşünceleri nefrete varacak boyutta filmleştiren kimi yönetmenler uzun tarihsel süreç içinde insanlığın kat ettiği yolu görmeyi red etmekte sadece bardağın boş tarafına bakmaktadır. Bu noktada olumsuz düşüncelerin yayıcısı olan yönetmeler, sı̆̆ bir iyimserlik yayıcısı olmadıkları için değil yaşamı bütünselliği içinde yansıtmadıkları ve insanın yapıcı potansiyeline güven beslemedikleri için yaşam karşıtı bir konuma sürüklenmektedir.

Yaşamı olumlu yönde dönüştürmeyi hedeflemeyen, sürekli insanın ve yaşamın sefaletini işleyerek varoluşun olumsuzluğuna dövünen ve bu olumsuzlukları yaşam karşıtlığ 1 formunda estetize eden bir sinema, insana sadece pesimizmi vaaz edebilir. $\mathrm{Bu}$ bağlamda Türk sinemasında 1980'li yıllarda asistan olarak çalışmaya başlayan ve ilk filmi $C$ Blok ile başladığı yönetmelik kariyerine hâlihazırda 11 film sığdıran Zeki Demirkubuz'un sinema anlayışı insan realitesine bakışı üzerinden irdelenecektir. Bu doğrultuda Varoluşçu düşünce ve Fyodor M. Dostoyevski' nin birkaç argümanını kendine göre yorumlama iddiası içinde olan Demirkubuz'un filmleri kurgusal karakterlerin niteliği ve davranışları üzerinden betimlenerek, yönetmenin filmlerinde dişavurduğu insan anlayışı nitel yaklaşımla incelenecektir. Bu doğrultuda insanın ontolojik olarak kötü olduğu motivasyonuyla hareket ettiği düşünülen Demirkubuz'un filmleri mizantropi kavramı bağlaminda irdelenecektir. Bu eksende makalenin temel amacı, sinema alanında insana yönelik olumsuz yaklaşımın bir boyutu olan mizantropinin Demirkubuz'un filmlerinde temel motif olduğunu açı̆̆a çıkarmaktır. 


\section{Mizantropi Kavramı}

Mizantropi insanları sevmemek, insanlardan nefret etmek, güvenmemek ve insanlığ1 hor görmek anlamına gelen bir kavramdır. Bu türden düşünce ve duyguları taşıyan kişiler ise mizantrop olarak nitelendirilmektedir. Düşünce tarihinde mizantropinin nedenleri farklı gerekçelere dayandırılarak açıklanmıştır. Batı felsefesinde mizantropinin tartışıldığı ilk yazılı metinlerden olan Phaedo adlı diyalogta konuyu Sokrates üzerinden ele alan Platon, insanların nadir olan aşırılıklarının onları korkunç ya da mutlak anlamda kötü yapmadığını sadece insan olduklarını ortaya koyduğunu savunur. Platon açısından, ortalama insanın çok iyi olması gerektiği beklentisi yanlış bir düşüncenin üründür ve bu türden hatalı bir beklenti içine giren kişi ummadığı sonuçla karşılaştığında mizantrop olma ihtimali ortaya çıkmaktadır. Bu nedenle bir insanın diğer insanlardan nefret etmesinin temelinde, insanlarla ilgili yanlış bilgi ve değerlendirmelere dayanan beklentiler bulunmaktadır (Plato, 2011:82). İnsanı siyasal bir hayvan olarak gören Aristoteles, “Düpedüz bahtsızlığından değil de doğası gereği, şehri, devleti olmayan bir kimse ya fazla iyidir ya fazla kötü , ya insanlığın altındadır ya üstünde" (1975:9), çıkarsamasında bulunarak insanın doğası gereği sosyal ilişkiler kurmak durumunda olduğunu ve bu ilişkiler içinde anlam kazandığını belirtmektedir. Bu durum Aristoteles'in insanı toplumsal bir varlık olarak gördüğünü ve bu çerçevede gelişen yaşam pratikleriyle insanın mizantrop olup olmamasının belirleneceğine işaret etmektedir. John Jowett (2004)'e göre, Aristoteles geleneğinde sosyal örgüt, insan davranışının temel bir parçasıdır. Bu nedenle anti - sosyal insan bir anormallik ve çelişki oluşturmaktadır, dolayısıyla Aristoteles çizgisindeki erken dönem bakış açısına göre mizantropi bir çeşit canavarlık olarak görülmektedir (29). Rasyonalist filozof Immanuel Kant mizantropiyi insanlardan çekinme ve insanlara karşı düşmanlık olmak üzere iki farklı boyutta ele almaktadır. Kant (1997)'a göre, mizantropi birinci haliyle insanlardan çekinmek, hoşlanmamak ve kaçınmak biçiminde gerçekleşmektedir. Mizantropinin bu boyutunda herkesi kendine düşman görmeye dayanan korku bulunmaktadır. Bu korku mizaçla ilintilidir. Bu tür mizantroplar, çekiniktir, kendilerini diğer insanlardan daha aşağı ve eksik gördükleri için toplumsallaşmazlar ve insanlardan kaçarlar. Belirli bir düzeyde onur sahibi oldukları için gizlenmeyi seçerler. Bu mizantropların insanlardan kaçması kısmen hoşnutsuzluktan kısmen de insana karşı olmalarından kaynaklanmaktadır. Mizantropinin ikinci boyutu ise insandan tür olarak hoşlanmamakla ilgilidir. Bu tip mizantroplar, insandan hoşnutsuzdur, insanları sevmemekte, herkesi kötü saymaktadır. Bu türdeki mizantroplar insanları kendi arzu ve taleplerine uygun görmeyen melankoliklerdir. İnsanlara karşı besledikleri kötü niyet yüzünden insanların kötülüğünü isterler (191). İrrasyonalist düşünür Friedrich Nietzsche (2014), nefretin farklı türleri olabileceğini, kimi insanların sadece kendilerini zayıf ve yorgun hissettiklerinde nefret ettiklerini; diğerlerinin ise sadece intikam olanağ1 belirdiğinde nefret ettiklerini (224-225) ileri sürmekte, dolayısıyla nefretin güç dengesi ve değişen koşullara bağlı olarak ortaya çıktığını savunmaktadır. Psikanalist Sigmund Freud, politik felsefenin önemli ismi Thomas Hobbes tarafından popülerleştirilen 
"homo homini lupus"1 sözünün yaşam ve tarihin bütün deneyimleriyle geçerliliğini koruduğunu vurgulayarak, insanın yapısı üzerine Hobbes'a benzer karamsar görüşler öne sürmüştür. İnsan insanın kurdudur, sözünün insanın tarihsel pratikleriyle geçerliliğini koruduğunu vurgulayan Freud (2011:69)'a göre,

Bu korkunç saldırganlık, kural olarak, ya bir kışkırtma kollar ya da kendini, hedefine aslında daha yumuşak yöntemlerle de erişilebilecek bir davanın hizmetine koşar. Koşullar elverişli olduğunda, kendisini normalde ketleyen karşıt ruhsal güçler ortadan kalktığında, saldırganlık kendiliğinden ortaya çıkıverir; insanı, kendi türüne karşı merhamet nedir bilmeyen vahşi bir canavar olarak ortaya çıkarır .

İnsan doğasına bakışındaki karamsar düşünceler Freud'u radikal toplumsal değişmeler olsa dahi insanın kötücül yönlerinin devam edeceği konumunda tutmuştur.

İnsanı sınıf mücadeleleri ekseninde değerlendiren Karl Marx, Feuerbach üzerine yazdığı altıncı tez'de "İnsani öz tek tek her bireyin doğasında bulunan bir soyutlama değildir. Bu öz, kendi gerçekliği içinde, toplumsal ilişkiler bütünüdür" (2013:16), çıkarsamasında bulunarak, insanın salt iyi ya da kötü olmadığını insanın toplumsal ilişkiler içinde şekillendiğini vurgulamaktadır. Bu doğrultuda insanın mizantrop olması toplumsal ilişkiler, özel mülkiyet ve üretim ilişkilerinin belirleyiciliğinde oluşmaktadır. Bu açıdan Marx'ın insan anlayışı insanın mutlak anlamda iyi ya da kötü olduğu yönündeki düşünceleri red etmektedir. Marksist kuramda ileri sürülen özel mülkiyet ve sınıfsallıkla ilgili sava karşı çıkan Freud (2011:71), Marksistlerin savunduğu özel mülkiyetin kaldırılması ve sınıfsız toplum yaratama düşüncesinin insanın yapısına içkin olan mizantropik eğilim ve yaklaşımlarına çözüm üretemeyeceğini ileri sürmektedir:

Maddi nesneler üzerindeki kişisel hak ortadan kaldırılsa bile, diğer açılardan eşit kılınmış insanlar arasında en güçlü kıskançlık ve en şiddetli düşmanlık kaynağı olarak cinsel ilişki ayrıcalığı varlığını sürdürecektir. Cinsel yas min tümüyle serbest hale getirilmesi, yani uygarlı̆̆ın tohumu olan ailenin ortadan kaldırılması ile bu ayrıcalığın da yok edilmesi durumunda, uygarlığın gelişiminin nerelere varacağını önceden kestirmek kolay değildir; ancak, insan doğasının yok edilemez özelliğinin burada da uygarlığın peşini bırakmayacağını tahmin edebiliriz.

İnsan doğası konusunda Freud kadar karamsar olmayan psikanalist kuramcı Erich Fromm'un betimlediği biçimiyle, sadist ${ }^{2}$ bir eğilim olan başkalarına acı çektirmek, başkalarının acı çektiklerini görmek onları aşağılamak ve zayıflıklarını ifşa etmek eğilimi

\footnotetext{
1 İnsan insanın kurdudur anlamındaki Latin sözüdür. Thomas Hobbes (1588-1679) tarafından popülerleştirilmiştir. Hobbes bu sözlerle insan doğası üzerine karamsar görüşlerini özlü biçimde açıklamıştır. Bu yaklaşım insanın yapısı gereği öteki insanlara düşmanlık beslediğini, mizantropinin insanın doğasına içkin olduğunu ileri sürmektedir.

2 Georges Bataille Edebiyat ve Kötülük adlı eserinde, sadizmi yıkımı izlemekten alınan zevk ve kötülükle özdeşleştirerek tanımlamaktadır. Bkz.(2004:16).
} 
insanın doğasına ve eylemlerine karşı güvensizlik ve nefretin ifadesi olan mizantropi ile ilişkilidir. Fromm, The Fear of Freedom (2001)'da birbirleriyle ilişkili üç çeşit sadist eğilimden söz etmektedir : Bu eğilimlerden ilki diğer insanların üzerinde sınırsız otorite kurma amacıyla onları kendine bağlamaktır. İkinci sadist eğilim kişiler üzerinde otorite kurmanın sınırlarını aşarak onların her şeyini sömürmek biçimindedir ve bu eğilimdeki arzu maddi veya zihinsel olan şeyleri de kapsamaktadır. Üçüncü sadist eğilim ise öteki insanlara acı çektirmek veyahut acı çektiklerine tanık olmak arzusunu içermektedir. Burada söz konusu olan acı çektirme zihinsel ya da bedensel olabilmektedir ancak zihinsel acı çektirme daha çok arzulanmaktadır. Bu eğilimde söz konusu olan amaç diğer insanlara etkili biçimde acı vermek, alçaltmak veya onları utanç verici biçimlerde ve aşağılayıcı durumlarda görmektir (124). Fromm'un görüşlerine ters düşmeyecek biçimde insanın insandan nefret etmesinin nedenlerini açıklayan psikanalist kuramcı Arno Gruen (2010)'e göre insanlar yaşadıkları aşağılanma deneyimlerini tekrar yaşamamak ve kendilerini zayıf hissetmemek için çektikleri acı ve eziyetleri itiraf etmeyi alçaltıcı bulmaktadır. Bu durumu aşmak ya da üstesinden gelmek için ise başka insanları aşağılamak, onlara eziyet etmek ve onları fethetmek zorunlu bir hal almaktadır. Bu doğrultuda itaat ve şiddet kültürünün egemen olduğu toplumlarda yaşanan deneyimlerin birey üzerinde çeşitli tahribatlara yol açabildiğini, belirten Gruen'e göre bu biçimdeki "sosyalleşme, bilinçli veya bilinçsiz, kendilik değerinin başkalarını aşağılayarak ve alçaltarak elde edilebileceği ilkesini öğretir. Yani, ötekini ezmek kendini iyi hissetmenin koşulu haline gelir. İnsanda, kendi varoluşunun, kendi algılayış ve ihtiyaçlarının baskı altına alınmasına tepki olarak müthiş bir nefret potansiyeli gelişir" (7980). Bu doğrultuda insanın mizantrop olması ve alçalmadan aldığı haz arasında ilginç bir görüş yazar Orhan Pamuk tarafından şöyle yazılmıştır :

Aşağılanmanın zevklerini hepimiz biliriz. Peki, şöyle düzelteyim: Kendi kendimizi aşağılamanın zevkli, rahatlatıcı olduğunu keşfettiğimiz zamanları hepimiz yaşamışızdır. Aşağılık, beş para etmez biri olduğumuzu, kendimizi inandırmak ister gibi, öfkeyle kendi kendimize tekrarladığımızda, bir anda herkes gibi olmanın bütün o ahlaki yükünden, kurallara ve yasalara uymanın boğucu endişesinden, herkese benzemek için dişimizi sıkmak zorunluluğundan kurtulduğumuzu biliriz. Başkaları tarafından aşağılanmak da, başkalarından önce davranıp kendi kendimizi herkesten önce aşağılamak da sonunda bizi ayn yere getirir. Kolayca kendimiz oluverdiğimiz, kendi kokumuz, pisliğimiz, alışkanlıklarımız içerisinde mutlu olduğumuz, kendimizi iyiye doğru değiştirmekten ve insanoğlunun geri kalanı hakkında iyimser düşünceler beslemekten vazgeçtiğimiz yerdir burası. Bu son nokta o kadar rahattır ki, bizi bu özgürlük ve yalnızlık noktasına getiren öfkemize ve bencilliğimize neredeyse şükran duyar, sık sık hatırlarız onları (2007:5).

Pamuk'un bu görüşleri bir acziyet ve alçalma durumu olan mizantropluğun self refleksif yönüne işaret emesi açısından dikkat çekicidir. Bu durum mizantrop insanların kendilerinden de nefret ettiklerine yönelik psikanalitik yaklaşımla örtüşmektedir. Fromm (2001)'a göre, mazoşist sapkınlık acı çekme ya da aşağılanmadan bilinçli ve kasıtlı zevk alma 
durumundur. Bu durum psikolog ve yazarların dikkatini, mazoşist karakterden ya da moral alanındaki mazoşizminden önce çekmiştir (127). Bu doğrultuda mizantropi kendisiyle barışık olmayan sağlıksız kimselerin muzdarip olduğu hastalıklı bir olgu olmaktadır.

İnsanlıktan ya da tür olarak insandan nefret etmenin karmaşık ve farklı nedenleri söz konusu olabilmektedir. Bu çerçevede mizantropiyi insanlığın sonunu getirebilecek antinatalizme kadar vardıran ancak bunun mizantropi olmadığını tersine filantropi olduğunu savunan radikal görüşler de bulunmaktadır : "Vardığım sonuçlar birçok insana mizantropik gelecek. Hayatın hoşnutsuzluk ve acıyla dolu olduğunu, çocuk yapmaktan kaçınmamız gerektiğini ve insanlığın sonunun mümkün olan en erken zamanda gelmesinin iyi olacağını savundum" (Benatar, 2018:245). Mizantropik düşünceler genel olarak Benatar'ın savunduğu insanın tür olarak yok edilmesi önerisine kadar vardırılmaz ancak temel olarak antihümanist bir öz barındırır ve insana sempati ya da herhangi bir övgü içermez.

\section{Zeki Demirkubuz'un Mizantrop Tutumu ve Filmlerine Yansıması}

Dünya görüşü genelleştirilmiş duyarlılıklar ve insanın dünya ile, kendisiyle ve diğer insanlarla kurduğu çok yönlü ilişkiler sistemidir (Spirkin, 2016:29). Vurgulandiğı üzere çeşitli psişik ve düşünsel motivasyonlardan kaynaklanan mizantropi, insanın dünya görüşünü oluşturan dinamiklerle ilişkilidir. Bu eksende sinema alanında mizantropinin irdelenmesi için yaratıcı yönetmenlerin insan realitesine ve yaşama bakışlarını oluşturan düşünsel dinamikleri açıklamak gerekmektedir. Bu durum özellikle filmlerin, yönetmenin öznel konumu bağlamında odağa alınarak değerlendirildiği, auteur yaklaşım için önem taşımaktadır.

Auteur nitelemesi, filmlerinde stil ve tema tutarlılığ görülen yönetmenlerin yaratıc1 olarak nitelendirilmesi (Buckland, 2013:84) çerçevesinde yapılmaktadır. Bu bağlamda auteur'lük, bütün çalışmalarının arkasında en baskın ve en temel itici güç unsuru, 'kişisel dünya görüşü' olan yönetmenleri (Hunt, vd., 2012 : 16), tanımlamaktadır. Söz konusu kategoride değerlendirilen yönetmenler yaratıcı özelliklerinin güçlü olması ve imza attıkları filmlerin oluşumunda temel belirleyici olmaları bağlamında "auteur" statüsünde değerlendirilmektedir. Genel hatlarıyla tanımlandığı biçimiyle Demirkubuz, çeyrek asrı aşan sinema kariyerinde C Blok (1994), Masumiyet (1997), Üçüncü Sayfa (1999), Yazgı (2001), İtiraf (2002), Bekleme Odası (2003), Kader (2006), Kıskanmak (2009), Yeraltı (2012), Bulantı (2015) ve Kor (2016) adlı filmlerinde ortaya koyduğu tematik süreklilik, oluşturduğu estetik tarz ve farklı yazarlara ait romanları kendine özgü biçimde uyarlamasıyla auteur kategorisi içinde değerlendirilebilecek nitelikleri taşımaktadır. Bu doğrultuda Demirkubuz'un filmlerindeki temel motifleri besleyen insana yönelik tutumu yönetmenin ilişkilendirildiği düşünsel temeller ekseninde irdelenecektir.

Jean-Jacques Rousseau, "Ruh hiç farkında olmadan uğraştığ1 işlerin düzeyine alçalır veya yükselir" (2007:32), saptamasında bulunmakta; Nietzsche ise "Ucubelerle savaşanın bu 
arada kendisinin de bir ucubeye dönüşmemeye dikkat etmesi gerekir. Uzun süre bir uçuruma bakarsan, uçurumda senin içine doğru bakar" (2016:90), uyarısında bulunmaktadır. $\mathrm{Bu}$ bağlamda insanın yaşam pratiği, yaşam tarzını ve kişiliğini belirleme potansiyeli taşımakta ve kişinin uğraştığı meseleler onun yaşama ve insana bakışını belirlemektedir. Bu durum auteur olarak tanımlanan yaratıcı yönetmenler için de geçerlidir. Belli motifler üzerinde yoğunlaşan auteur yönetmenler ele aldıkları konulara yaklaşımlarıyla üzerinde durdukları izlek ve olaylar tarafından etkilenmektedir. Bu çerçevede söz konusu yönetmenlerin ilgi ve deneyimleri yaşama ve insana bakışlarının oluşumunda etkin rol oynamaktadır. Bu doğrultuda denilebilir ki mizantropik bir yaklaşımla filmsel karakterleri kurgulayan yönetmenler yarattıkları karakterler üzerinden kurgusal düzlemde bir çeşit kendini gerçekleştirme, insana dair düşüncelerini açılama ve arınma yoluna gitmektedir.

Estetik kuramcısı Avner Ziss, “Bir roman kişisinin yaşantısı yaratıcısının yaşamından ayrılamaz. Her sanatçı, az ya da çok, yarattı̆̆ı kişilerin içinde yaşar" (2016:80), biçimde yaratıcı ve eseri arasındaki ilişkiyi açıklayan önemli bir çıkarımda bulunmaktadır. Ziss'in bu çıkarımı auteur yönetmenlerin dünya görüşünün filmlerine yansıması için de açıklayıcı niteliktedir. Bu eksende, Semire Ruken Öztürk (2006), ile gerçekleştirilen bir röportajda, “Bir sinemacı bence kendi özünden, kendi dünyasından çıkarabildikleri ile sinemacıdır"(92), görüşünü benimsediğini açılayan Demirkubuz, yaşamı ve filmleri arasında olması gereken ilişkiyi kendi sözleriyle ifade etmektedir. Söz konusu röportajda Demirkubuz, “Ben güçlü bir insan olduğum için inançsızlaştım, ideolojilerden, dogmalardan vazgeçtim. Diğeri zayıf ve çaresiz insanların mecburiyetidir." (2006:109), diyerek kendisini "sıradan" insanlardan farklı bir yerde konumlandırmaktadır. Bu eksende insanın ontolojik olarak kötü olduğu düşüncesini temel alan ve bu doğrultuda filmler üreten Demirkubuz'un kurgusal kahramanlara reva gördüğü, şiddet, alçaltma, aşağılama ve değersizleştirme biçimindeki mizantropik yaklaşım, yönetmenin yaşadığı deneyimlerin dışavurumu ve sağaltımı açısından anlam bulmaktadır. Demirkubuz "iyi" ve "kötü" insanlar ve eylemleri arasındaki ayrımı güç ve zekâyla ilişkilendirerek, "İyiler genellikle böyledir, adamın zaten iyi olmaktan başka bir çaresi yoktur. Kötülük yapamayacak kadar zayıftır, kötü olamayacak kadar zekâ yoksunudur, o adam zaten iyi olacak, onun başka çaresi yok, doğası böyle" (2006:118), şeklinde açıklamaktadır. Bu yaklaşımıyla insan fenomenine bakışını kötülük olgusu ekseninde inşa eden Demirkubuz iyiliği zayıf, çaresiz insanların mecbur kaldıkları bir davranış ve savunma mekanizmasına indirgemekte ve filmlerindeki mizantropik konumlanışını bu temel üzerinden savunmaktadır.

Modern kötülük anlayışında, kötülük kategorik olarak yıkıcı ve zarar verici bir niyet ya da istencin varlığına dayanmaktadır. Kötülük, şeylere içkin ve doğal değildir, insan ilişiklerinin sonucunda ortaya çıkmaktadır ve siyasete bağlı olarak üretilen bir kategoridir (Oranlı, 2017:26-29). Kötülük hakkındaki bu önermeler insanla ilgili temel bir gerçekliğe işaret etmektedir. İnsanın eylemleri toplumsal ilişikler içinde şekillenmektedir, iyilik ve kötülük insanda bulunan potansiyellerdir ve mutlak anlamda iyi ve kötü insan zorlama bir 
nitelendirme olmaktadır. Bu bağlamda bir yönetmenin tema olarak kötülüğü seçmesi tek başına mizantrop olduğunu kanitlamaz ancak kötülüğe yaklaşımı ve insanla kötülük arasında kurduğu ilişkinin yansıtılması, mizantropluğun göstergesi olabilir. Bu doğrultuda Demirkubuz'un insanın "düşürülmesi" yönündeki görüşleri mizantropluğunun bir göstergesini oluşturmaktadır: “Gücün yenilmesini görmek eğlenceli bir şey, insanın kötücül yanlarından biri bu. Mazlum gibi görünen ya da zayıf gibi görünen takımı tuttuğum için falan da değil, sadece güçlünün o hale geldiğini görmek eğlenceli geliyor" (2006:121). Bu sözlerden anlaşılacağı üzere Demirkubuz güçlü insana karşı hınç içeren düşünceler beslemektedir. Bu yaklaşımın dışavurumu ise birçok filmde güçlü görünen karakterlerin güçten düşürülmesi, dahası "zayıf" ve "güçsüz" olanların daha da alçaltılması ve acınası hale düşürülmesinde görülmektedir. Bu durum Demirkubuz'un 1994 tarihli ilk filmi C Blok'ta yüzeysel biçimde Tülay (Serap Aksoy) ve Halit (Fikret Kuşkan) adlı film karakterleri üzerinden başlamaktadır. Tülay sınıf atlamak için evlenmiş mutsuz bir kadın olarak, bunalım içindedir, eşi Tülay'ı, Tülay da eşini aldatmaktadır³. Film aldatmaya doymayan insanların, yapay bunalımları, kasvetli mekanlar ve absürdleşen cinsel fantezilerle ilerlemektedir. Karşı1ıklı aldatmalar, tecavüzler ve bunalım ekseninde kurulan kopuk kurgu ve derinlikten yoksun anlatı Tülay ile ilişkiye giren Halit'in aklını yitirmesiyle son bulmaktadır. C Blok bir ilk film olmanın zaaflarını taşımakla birlikte Demirkubuz'u auteur'lüğe taşıyacak mizantrop yaklaşımı aldatma, kötülük, bunalım ve erkekleri yıkıma götüren kadın imgesi gibi nitelikleri içermesiyle dikkat çekmektedir. C Blok'tan sonra 1997' de gösterime giren Masumiyet ve devamı niteliğindeki 2006 tarihli Kader yönetmenin mizantrop yaklaşımını daha açık biçimde belirginleştirmektedir. Adı geçen filmlerde Bekir (Haluk Bilginer \& Ufuk Bayraktar) ve Uğur (Derya Alabora \& Vildan Atasever) arasında eşi az görülebilecek bir ilişki üzerinden senaryo kurgulanmaktadır. Bekir orta sınıfa mensup işinde gücünde bir erkektir, Uğur ise aynı mahallede yaşayan bir fahişedir. Bekir, Uğur'a hastalıklı biçimde bağlanmakta ve Uğur tarafından reddedildikçe düşkünleşmektedir. Bekir rasyonellikle açıklanmayacak biçimde Uğur'u önemsemekte, fetiş haline getirmekte ve elde edemedikçe alçalmaktadır. Masumiyet ve Kader adlı filmlerde Demirkubuz Bekir'e acımamaktadır, karakterini sevmemektedir ve sürekli alçalttığı Bekir'i yozluğun batağındaki bir pezevenk olarak intihara sürüklemektedir.

Nietzsche yozlaşmayı, kişinin içgüdülerini yitirmesi, kendisine zararlı olanı seçmesiyle (2008:12) açıklar. Bu açıdan Demirkubuz'un yarattığı kahramanların yoz oldukları açıktır. Öyle ki, Demirkubuz'un filmlerinde sınıfsallık, eğitim durumu, kültür farkı olmaksızın insanlar kendilerine ya da diğer insanlara zarar vermekte veya anlaşılması zor, saçma eylemlerde bulunmaktadır. Bu açıdan yozlaşmaya doymayan Bekir, Demirkubuz'un yarattığı en yoz erkek karakterdir ancak yozluk Bekir'le ve erkek karakterlerle sinırlı

\footnotetext{
3 İnsanların birbirlerini aldatması Demirkubuz'un bütün filmlerinde yer almaktadır. Filmlerde eşler birbirini
} aldatmaktadır ancak kadınların aldatması daha belirgindir ve yıkıcı sonuçların nedeni olarak işlevseldir. 
kalmamaktadır, Uğur, Bekir'in çökmesinde femme fatale ${ }^{4}$ konumundadır ancak kendisi için de zararlı seçimlerde bulunmakta ve bataklığa sürüklenmesi derinleşmektedir. Bu eksende yozluk Demirkubuz'un yarattığı birçok kahramanın belirgin karakteristik özelliğini oluşturmaktadır.

\section{Zeki Demirkubuz, Dostoyevski ve Varoluşçu Dïşünce'nin Tersyüz Edilmesi}

Demirkubuz, kendisini Fyodor M. Dostoyevski ve varoluşçu düşünceyle ilişkilendirmekte, bu ilişkiselliğini çeşitli röportajlarda ${ }^{5}$ dile getirmektedir. $\mathrm{Bu}$ durum Demirkubuz'un filmlerine de yansitılmaktadır. Demirkubuz Yazgı, Yeraltı ve Bulantı adlı filmlerini sirasiyla Albert Camus, Dostoyevski, Jean - Paul Sartre' in eserlerinden esinlenerek oluşturmuştur. Bu filmlerle birlikte Üçüncü Sayfa, Bekleme Odası, Bulantı ve Kıskanmak'ta açık ya da örtük biçimlerde Dostoyevski ve Varoluşçu felsefeye göndermeler bulunmaktadır. Bu doğrultuda varoluşçu düşüncenin temel argümanlarını açıklamak filmlerde söz konusu felsefeye yapılan göndermelerin niteliğini anlamak için yaralı olacaktır.

Varoluşçu düşüncenin insana dair en popüler aforizması "varlığın içine atılmışlık" ifadesidir. Lukacs (1975)'a göre, Martin Heidegger insanın varoluşunu "varlığın içine atılmışlık" olarak betimleyerek bireyin ontolojik yalnızlığını çarpıcı biçimde açıklamaktadır ancak bu yaklaşım insanın anlaşılmaz ve anlamsız olarak dünyada bulunduğunu da ifade etmektedir (23). Böylece insan anlamsız biçimde içine atıldığı dünyada anlam arayışı içine girmektedir. Gaidenko (1966)'ya göre, Varoluşçuluk en genel özelliğiyle bireyin sürü içinde kaybolmasına bir tepkidir. Öyle ki varoluşçular, Hegel felsefesinde "mutlak ruh"un gelişmesinde sadece bir unsur olarak görülen bireyi öne çıkararak tümel karşısında tikeli savunmaktadır (34). Dostoyevski ve varoluşçuluk ilişkisi ise özellikle yazarın Yeraltından Notlar novelası üzerinden kurulmaktadır. Walter Kaufmann (1965)'a göre, Dostoyevski'ye varoluşçu demek için hiçbir neden yoktur ancak Yeraltından Notlar varoluş̧̧uluk için yazılagelmiş en iyi başlangıç yapıtıdır; varoluşçuluğa içkin belli başlı konular, eşsiz bir güçle ve incelikle bu eserde ortaya konmuştur (10). Schaff (1966)'a göre, insanın kendi eylemlerindeki kişisel sorumluluğu, hayatın anlamı ve bireyin dünyadaki yeri ve rolü gibi sorunlara yapılan aşırı vurgu varoluşçuluğu çekici kılmaktadır (24). Varoluşçu düşünce, başka bir felsefi akımda olmadığı kadar bireyle toplum arasındaki çatışmayı anlaşılabilir ve kesin biçimde ortaya koymuştur (Gaidenko, 1966:32). Demirkubuz'un filmlerinde ise birey ve toplum arasında çatışma ya da çelişki söz konusu dahi edilmemektedir. Filmlerde kendileriyle ve öteki kişilerle sorunlu bireyleşememiş insanlar söz konusudur. Birey ve

\footnotetext{
${ }^{4}$ Femme fatale : Fransızca kökenli bir tanım. İlişkiye girdiği erkeklerle sonunda büyük sıkıntılar yaşatan çekici ve baştan çıkarıcı kadın. Fransızca' da "felakete neden olan kadın" anlamına gelir. Demirkubuz' un filmlerinde kötü kadın imgesi genellikle "güzel" ve "çekici" kadınlarla ilişiklidir ancak Kıskanmak ve Yeraltı'nda "çirkin" kadınlarda kötülükle ilişkilendirilmektedir.
}

5 Zeki Demirkubuz : “Dostoyevski Olmasaydı, Edebiyat Olmasaydı Sinemacı Olmazdım”. Bkz.(Pay ve Afat, 2009, s.105-106). 
toplum arasındaki çelişkilerin sorun edilmesi söz konusu bile değildir, alt ya da orta sınıfa mensup tüm kahramanlar olumsuz özellikleriyle bunalım halinde gösterilmektedir. $\mathrm{Bu}$ çerçevede Demirkubuz'un "kahramanlar" 1 bireyden çok "insancıklar"dır ve kişisel sorumluluk alabildikleri tartışmalıdır çünkü filmlerdeki birçok karakter yalnızca "kader"lerinin peşinde sürüklenen yoz "yazgı"lardan memnun olan "bulantı"ya tutulmuş insanlardan oluşmaktadır.

Freud, Dostoyerski ve Baba Katilliği adlı makalesinde, Demirkubuz'un alçalttığ1, düşkünleştirdiği ve bu yöntemle "iflâh etme" çabası içine girdiği insan tipinin, anlaşılmasına katkı sunacak saptamalar bulunmaktadır. Freud (2001:9)'a göre;

Ahlâkın doruğuna erişilebilmesi için herhangi bir kimsenin korkunç günahlar işlemesi gerektiğini ileri sürerek Dostoyevskinin büyük bir ahlâkçı olduğunu söylemeye kalkarsak, ortaya çlkacak bir şüpheyi görmezden gelmiş oluruz. Ahlâklı kimse, şeytana uyduğunu anlar anlamaz, direnen ve kendini kurtaran kimsedir. Bir yandan günah işleyen, öte yandan pişmanlık duyduğu zaman ahlâksal kurallar ortaya koyan bir kimse işi kolayından alıyor demektir. Çünkü ahlâksal bir davranış her şeyden önce pratik bir insancıl değer taşımaktadır. İşi kolayından alan kimse, eski çağların barbarlarına benzer bir davranış tutturmuştur. Eski çağ barbarları, önce adam öldürüyor sonra pişmanlık duyuyorlardı. Böylece, pişmanlık duymak, insan öldürmeyi sağlayan bir teknik haline gelmişti.

Freud'un Dostoyevski ve eski çağ barbarları üzerinden açıkladığı arınma sistemi Demirkubuz'un filmlerinde yapay biçimde taklit edilmektedir. Demirkubuz önce kahramanlarına acı çektirmekte, aşağılamakta, düşüşlerine yol açmakta ya da onları utanç verici eylemlere sürüklemektedir. Alçalma ve yozlaşmada dibe vuran kahramanlar için ise diplerde bir dinginlik söz konusu olmaktadır. Bu durum ise kurtuluş ya da yükselmenin başlangıcı olmamaktadır. Dibe vuran ve alçalmanın hafifliğine teslim olan kahramanlar ile Kıskanmak ve Üçüncü Sayfa'da olduğu gibi kötücül eylemleriyle hedeflerini bir ölçüde gerçekleştiren karakterler arasında herhangi bir arınma ya da insanı yüceltecek bir değişim söz konusu olmamaktadır. Freud, Dostoyevski'nin bir yöntem olarak kendini rahatlatmak için küçük düşürme yoluna başvurduğunu belirtmektedir.

Dostoyevski, son meteliğine kadar kaybetmeden rahat edemiyordu. Dostoyevski için, kumar da bir çeşit kendini cezalandırma yöntemiydi. Genç karısına artık hiç kumar oynamayacağı sözü ya da belli bir gün kumar masasının yanına yaklaşmayacağı konusunda namus sözü veriyor, ama bu sözünü hiçbir zaman tutmuyordu. Kumar yüzünden parasız kalarak kendini ve karısını feci bir duruma düşürdüğü zaman da, bundan patalojik bir doygunluk sağlıyordu. Karısının karşısında, kendini küçük düşürüp gülünç hale sokuyor; karısının kendini küçümsemesini ve günah işlemekten vazgeçmeyen bir adamla evlenmiş olduğu için acınmasını istiyor ve vicdanına çöken yükü böylece attıktan sonra yeniden eski hayatına dönüyordu (Freud , 2001: 21). 
Freud'un net biçimde açıkladığı bu durum hastalıklı bir kişiliğin sağlıksız ve yoz bir çözüm yöntemi olarak Demirkubuz'un filmlerinde görülebilmektedir ancak çoğu kez bir sağaltma yöntemi olarak değil bir alçaltma ve insanı küçük düşürme yöntemi olarak.

Dostoyevski'nin romanlarındaki karakterler genellikle sorunlu ve sıradışı insanlardan oluşmaktadır. Bu durum Dostoyevski'den oldukça etkilendiğini her fırsatta açıklayan Demirkubuz'un karakterlerinin de sorunlu olmasıyla benzer görülmektedir ancak bu benzerlik daha çok biçimsel düzlemde söz konusu olmaktadır çünkü Demirkubuz'un sorunlu, mutsuz, yüzü gülmeyen, sevgisiz insancıklarıyla Dostoyevski'nin ruhani açıdan huzursuz, çoğunlukla yoksul ve teolojik mantık eksenli kefaretle arınan insanları arasında önemli bir yapısal fark söz konusudur. Suçkov (2009)'un da ifade ettiği üzere, Dostoyevski, normal haldeki insan zihni kendisini pek az ilgilendirdiği ve kendisine dramatik gözükmediği için, çeşitli duygulanım düzeylerindeki insan bilincinin hasta, karanlıkta kalan yanlarını incelemiştir. Ama aynı zamanda, çeşitli toplumsal psikolojiler arasındaki mücadeleyi vermekle de hem çevrenin hem de toplumsal hayattaki ana çatışmaların karakteristik yanlarını ortaya koymuştur (184). Bu açıdan bakıldığında Demirkubuz'un sorunlu kişileri Dostoyevski'nin derinlikli kahramanları karşısında yapay ve toplumsal psikolojileri yansıtmada oldukça yüzeysel kalmaktadır.

Varoluşçular, sorunları ve sorunların çözümünü insanın öznel tutumlarıyla açıklar. Bu yaklaşıma göre, insan özgürleşmek için bedel ödemek, çile çekmek ve bunun için cesur olmak zorundadır (Gaidenko, 1966:51). Demirkubuz'un karakterlerinin çektiği acılar ve ödedikleri bedellerin ise özgürleşmeyle ilgisi yoktur, daha çok rasyonel olmayan tercihler ve alçalmayla ilgilidir. Dostoyevski'nin kahramanları acı çekerek arınmakta bir çeşit kefaret ödemektedirler ancak Demirkubuz'un acı çeken kahramanlarının ödedikleri kefaret alçalma ve dekadans dışında bir şey ifade etmemektedir. Masumiyet ve Kader'de Bekir yaşadığ1 acılarla yozluğun batağına sürüklenmekte, İtiraf'ta Harun, aldatma ve aldatılmanın verdiği acıyla çöküşü yaşamakta, Üçüncü Sayfa'da İsa (Ruhi Sarı) maruz kaldığ1 acıların yükünü taşıyamayarak intihara sürüklenmektedir. $\mathrm{Bu}$ çerçevede yozlaşma ve alçalma Demirkubuz'un filmlerinde neredeyse tüm kahramanların deneyimlediği bir izleği oluşturmaktadir.

\section{Zeki Demirkubuz Tarzı Mizojini}

Demirkubuz'un filmlerinde kadına nefreti ifade eden mizojini unsurları belirgindir. Kadınlar sözlü ve fiziksel şiddete maruz kalmaktadır. Bu durum nerdeyse yönetmenin bütün filmlerinde tekrarlanmaktadır. Şiddete maruz kalan, sevgisiz bırakılan ya da aldatılmaya maruz kalan kadınlar erkeklere karşı bir çeşit negatif direniş içine girmektedir. $C$ Blok'ta Tülay, İtiraf ta Nilgün (Başak Köklükaya), Üçüncü Sayfa'da Meryem (Başak Köklükaya, Masumiyet ve Kader'de Uğur, Kıskanmak'ta Seniha (Nergis Öztürk) ve Mükerrem (Berrak Tüzünataç), Yeraltı'nda Türkan (Nihal Yalçın), Bulantı'da, Özge (Cemre Ebuzziya) Kor'da Emine (Aslıhan Gürbüz), erkekleri aldatmaları, sadakatsizlikleri, komploların içine girmeleri, yalan söylemeleri ve birçok olumsuz eylemleriyle erkeklerin felaketine yol açmaktadır. Demirkubuz’un kadınlara yönelik yaklaşımı kadını özellikle de güzel kadınları, 
kötülük ve şeytani düşüncelerle özdeşleştiren çeşitli mitolojik ve teolojik temaların bir çeşit yansımasına dönüşmektedir. Demirkubuz, "Kadın erkek ilişkilerinde bile insanın o kötücül yanlarına ilgi duydum hep, o pis gerçekliğine ilgi duydum. Ama bu çocukluğumdan beri böyledir" (2006:83) diyerek, kötülüğe ilgisinin cinslerarası boyutunu açıklamaktadır. Bu açıdan bakıldığında yönetmenin filmlerindeki sevgisizlik, aldatma ve hastalıklı "aşk" anlayışının nedenleri Demirkubuz'un ilgi duyduğu "pis gerçeklik" kavramı ile açıklık kazanmaktadır.

Demirkubuz genellikle erkek karakterlerini kadın karakterler karşısında yenilgiye uğratır. Yönetmenin tüm filmlerinde kadınlar, erkekler tarafından sözlü ve fiziksel şiddet görür ancak yine de kadınlar erkeklerin felaketine yol açar. Bu durum, filmlerde tekrarlanan temel bir izlektir. Bu bağlamda İtiraf ve Bulantı'da erkek karakterlerin kadın karakterlerin ayağına kapanması özellikle dikkat çekmektedir. İtiraf ta Harun her türlü çabasına karşı kendisini aldatan eşi Nilgün'den kendisini rahatlatacak bir cevap alamamakta son çare olarak onun ayaklarına kapanarak ağlamaktadır. Demirkubuz Harun'a acımamaktadır, Harun intihar girişimi, itiraflar ve huzursuzluk sarmalında alçaldıkça alçalmaktadır. Demirkubuz Bulantı'da Ahmet (Zeki Demirkubuz) karakteri üzerinden insanı alçaltma yönünde daha ileri bir adım atmaktadır. Ahmet eşinin ve kızının bir kaza sonucu ölmesi karşısında üzülme belirtisi göstermez. Eşini ve küçük yaştaki kızını yitirmeyi sorun etmemesinin sorunlu olduğu bilincinin oluşturduğu bunalımı yaşayan Ahmet bir süre sonra sağlık kontrolünden geçer ancak fiziksel anlamda gayet sağlıklı olduğu anlaşılır. Ahmet içine girdiği bunalım sürecinde kadın arkadaşına ${ }^{6}$ karşı duyarsızlaşır, eski öğrencisiyle ilişki kurar. Bu süreçte ilişkiye girdiği kişinin erkek arkadaşı evi basar ve Demirkubuz filmlerinde temel izleklerden bir olan onur kırıcı olaylar yaşanır. Bulantı'da Ahmet, ev işlerine yardım eden Neriman adlı karaktere karşı müphem bir yönelim içine girer. Filmin gidişatı Ahmet'in yöneliminin cinsel nitelikte olabileceği doğrultusunda izleyiciyi hazırlar ancak yönetmen bu beklentiyi sonuçsuz bırakır. Ahmet yaşanan bir elektrik kesintisinden sonra Neriman'ın dairesine iner ve kadının ayaklarına kapanarak hüngür hüngür ağlar. Neriman filmden anlaşıldığı kadarıyla dul bir kadındır ve küçük yaşta iki çocuğu vardır. Topal olan Neriman'ın bir diğer özelliği ise "güzel" olmasına karşın seksüel açıdan cezbedici olmamasıdır. Neriman'ın masumiyeti, zayıflığı ve içinde bulunduğu yoksulluk Ahmet'in ona karşı cinsel yönelimine ket vurur. Bu nedenle Ahmet Neriman'ın ayaklarına kapanarak rahatlamaya yönelir. Ahmet'in Bulantı'da gerçekleştirdiği ayağa kapanma sahnesi İtiraf ta Harun'un gerçekleştirdiği eylemden daha dikkat çekicidir. Harun, eşi karşısında yaşadığı çaresizlik nedeniyle alçalmaktır oysa Ahmet içinde bulunduğu boşluk duygusuna karşı rahatlamak için kültür, statü ve sınıfsal açıdan kendisiyle eşit olmayan "zavallı" bir kadının ayaklarına kapanmaktadır. Bulantı' da Ahmet'in gerçekleştirdiği ayağa kapanma davranışı

${ }^{6}$ Demirkubuz'un filmlerinde cinsellik ve cinslerarası ilişkiler merkezi bir konumdadır. C Blok, Kader, Kıskanmak ve Yeraltı'nda cinsellik içeren sahneler bulunmaktadır ancak Bulantı ve Kor'da cinsel ilişki daha açık ve kaba biçimlere bürünmektedir. 
Demirkubuz' un karakterlerini “alçaltarak rahatlatması" yaklaşımının yeni bir aşaması olarak dikkat çekmektedir. Demirkubuz'un önceki karakterlerinden İsa ve Bekir aşağılanma ve alçalma yoluyla "iflah" olmayarak intihar etmekte, Harun aynı şekilde intihar girişiminde bulunmakta, Kor'da Cemal (Caner Cindoruk) eşiyle ilişkisi olan Ziya (Taner Birsel)'nın atölyesinde çalışmayı seçerek yoz bir tavır içine girmekte, Yeraltı'nda arkadaşları ve gündelikçi kadın Türkan tarafından küçük düşürülen Muharrem (Engin Günaydın), evinindeki eşyaları kırıp dökerek, uluyarak ve zavallı durumdaki bir hayat kadınını aşağılamaya çalışarak huzur bulmaktadır. C Blok'ta Tülay'ın cinsel arayışı, Üçüncü Sayfa'da Meryem'in ve Kıskanmak'ta Seniha'nın komplolarla insanların yıkımını hazırlayarak huzur bulma çabası genel olarak Demirkubuz'un mizantrop yaklaşımını göstermektedir. $\mathrm{Bu}$ eksende kadınların yıkım gücü olarak konumlandırılması her filmde mizojininin tezahürü olarak tekrarlanmaktadır ancak gücünü yıkımdan alan kadın karakterler yücelerek arınmak yerine alçalarak ve çoğu kez Uğur örneğinde görüldüğü üzere kendilerini de yıkıma götürecek davranışlar sergilemektedir.

\section{Zeki Demirkubuz'un İnsan Realitesine Yaklaşımı}

Demirkubuz filmlerini, karakterlerin sınıfsal konumunu ve sosyo-kültürel statüleri ekseninde farklı7 iki kategoride konumlandırmaya çalışmaktadır. C Blok, Bekleme Odası, Yazgı, itiraf, Kıskanmak, Yeraltı ve Bulantı orta sınıfa mensup "okumuş-yazmış" kişiler ve onların çevresinde gelişen olaylar düzleminde kurgulanırken, Masumiyet, Üçüncü Sayfa, Kader ve Kor daha çok işçi sınıfı ve lümpen alt sınıf mensuplarından oluşmaktadır. Biçimsel düzlemdeki ikilik Demirkubuz'un insana yaklaşımını değiştirmemektedir. İlk kategorideki filmlerde Demirkubuz Yeşilçam melodramlarında klişe olan düşkün erkek ya da kötü kadın stereotipini yan karakter statüsünden ana karaktere taşımakta ve Yeşilçam filmlerinde karikatürize edilen bu stereotipleri daha özenli biçimde kurgulamaktadır. İkinci kategori içinde yer alan filmlerde insana bakış özsel olarak mizantrop niteliğini korumakta sadece kullanılan argo ağırlıklı dil yerini görece kitabi bir dile bırakmaktadır. İkinci kategoride tema felsefi görünümlü tartışmalara göndermeler içerse de bunalım, kötülük ve nihilizm olguları derinlikten yoksun biçimde kurgulanarak arabeskleştirilmektedir.

Demirkubuz filmleri doğal - organik bir bunalım ya da kötülük içermemektedir. Kötülügüün en planlı ve "sofistike" biçimde işlendiği Kıskanmak'ta bile Seniha, indirgemeci bir yaklaşımin ürünü olan ağabeyini kıskanmak gibi basit psikolojik gerekçelerle kötülük ediminde bulunmaktadır. Üçüncü Sayfa'da Meryem'in içine girdiği kötülük edimleri ise filmin adını oluşturan Üçüncü Sayfa haberlerindeki mantığı zorlayabilecek nitelikte yapay örüntüler içermektedir. Bu açıdan Demirkubuz filmlerindeki yapay kötülük pratikleri temelde küçük burjuvalara, lümpenlere ve daha çok alt sınıf mensuplarına yönelen kin, nefret ve alçaltma içeren mizantropik dışavurumu açıklamaktadır. Bu durum bir yandan başkalarının acılarına sevinme diğer yandan kendine zarar vermedeki hazla rahatlayan

${ }^{7}$ Söz konusu kategorizasyon mutlak ayrımlara dayanmamaktadır. 
ucube bir insan anlayışını dışavurmaktadır. Bu doğrultuda Demirkubuz'un tüm filmlerdeki leitmotif olan mizantropi sınıf ve kültür farkı olmaksızın tekrarlanmaktadır.

Sanat tarihçisi Arnold Hauser (1984)'e göre, insan doğasının değişmez bir nitelik taşıdığını kabul eden görüşler üzerine kurulan insanla ilgili düşünceler akıldışıdır ve tutuculuk öğesi içerir. İnsanın gelişim kapasitesine inanmamak, insanın ve onunla birlikte toplumun değişimini istememektir. Tutuculuk ve karamsarlık burada, karşılıklı olarak birbirlerini koşullandırmaktadır (398). Bu doğrultuda sadece kötülüğe ve insanın "karanlık" yönüne odaklanan Demirkubuz insanın dolayısıyla toplumun olumlu yönde değişebileceği görüşünün karşısında bulunmaktadır. Bu anlayış çağımızda yaşanan dekadans ve insanın yabancılaşması gibi olguları doğru okumayı engellemekte ve insanlığa karşı patolojik bir nefrete yol açmaktadır. Demirkubuz'un yaşamı bütünselliği içinde kavrama ve filmlere yansıtma gibi bir kaygısı bulunmamaktadır. İzleyici ve eleştirmenlerin görüşlerinden etkilenmediğini belirten Demirkubuz ne için film yaptığı sorusuna, "Orası meçhul, yani şunun için, bunun için, kendim için toplum için diye bir şey düşündüğümü hatırlamıyorum hiç..." ( 2006:115), şeklinde cevap vermektedir. Demirkubuz kötülüğgü, yozlaşmayı, bireyin bireye uyguladığı sömürüyü, şiddeti ve çirkinliği mizantrop bir tutumla ele almakta ancak "ne için ve kim için film çektiğini düşündüğünü hatırlamadığını" ifade ederek insana yönelik olumsuz ve tek boyutlu yaklaşımının amacının belirsiz olduğunu iddia etmektedir.

Bir yönetmen en açık biçimde yarattığı kurgusal kahramanlar ile insana verdiği anlamı açıklar. Bu bağlamda Yazg1 ${ }^{8}$ Demirkubuz'un dünya görüşünü doğrudan felsefi göndermelerle en belirgin biçimde yansıttığı film olarak öne çıkmaktadır. Bu eksende Demirkubuz, Musa (Serdar Orçin) adlı karakterin yaşama bakışı ve olaylar karşısındaki anormal tavrı üzerinden yoz nihilistik bir insan portresi inşa etmeye yönelmektedir. Musa üzülmeyen, sevmeyen, kıskanmayan, iradesini her öneri ve seçim karşısında "fark etmez" biçiminde ifade eden edilgin, yoz bir kişiliktir. Modern kapitalist toplumda bir kişinin, annesine yabancılaşması ya da doğal bir şekilde ölen yaşlı annesinin ölümüne kayıtsız kalması anlaşılabilir düzeydedir ancak "aklı başında" bir insanın, eşi tarafından aldatılmaya kayıtsız kalması, üstelik iki çocuğun anneleriyle birlikte öldürülmesi sonucu, kendisinin işlemediği bir cinayet yüzünden idamla yüz yüze kalmasına karşın, suçlamalara karşı duyarsız kalması en basit ifadesiyle yapay ve zorlama bir nihilist karakter yaratma çabasıdır. Musa gibi oldukça yapay bir karakter üzerinden işlenen düşünsel yaklaşım insanı ruhsuz, duygusuz kılmak dolayısıyla insanı karaktersizleştirmektir. Bu açıdan Musa karaktersiz bir karakterdir. Bu eksende filmde savunulan dünya görüşü dolayısıyla etik anlayış, savcının Musa'ya yönelttiği “Çocuk öldürmek iyi bir şey o zaman ?" Sorusuna Musa'nın “Çocuklar için iyi değildir ama yapan için iyidir", biçimindeki cevapta saklıdır. Bu cevapla Demirkubuz

${ }^{8}$ Demirkubuz, Yazgı için “Türk sinemasında yüz yıl geçse öyle bir film çekilmez" (Demirkubuz ve Öztürk, 2006, s.115) diyerek söz konusu filme atfettiği değeri vurgulamaktadır. Bu açıdan Yazgı yönetmenin filmografisinde özel bir konumda bulunmaktadır. 
insana ve yaşama bakışını yarattığı Musa karakteri üzerinden yoruma gerek bırakmadan açıklamaktadır.

Ernst Fischer (2012) , bir ideoloji ya da dünya görüşünün dolaysız övgüsünün etkisiz olma riski taşıdığını, buna karşın nihilistik kınamalarda devrimci bir yankının bulunduğunu, bu yönüyle karşı çıkma, isyan etme potansiyelinin amaçsızlığa yöneltilip edilgin bir karamsarlık doğurabildiğini, nihilist sanatçının her şeyi suçlayıp yadsımakla gerçekte egemen düzenin kucağına düştüğüne (109) dikkat çekmektedir. Fischer'in bu saptaması nihilizme yol açan bir yaklaşım olan insandan nefret etme durumu ve insanın doğası gereği kötücül olduğu biçimindeki ideolojik yaklaşım için de geçerledir. Mizantropinin açık biçimde savunulması yerine estetik bir formda sinema sanatının olanaklarından yararlanılarak estetize edilmesi, egemen sistemi ve bu sistem içinde şekillenen insanı değişmez kabul edip yeniden üretmekte ve insanı umutsuzluğa sürüklemektedir. Nietzsche (2016), "Bir insanın yüksekliğini görmek istemeyen, onda alçakta ve ön planda olan şeylere daha keskin gözle bakar - Böylelikle kendini ele verir" (219), demektedir. Bu durum bütün filmlerinde kötülüğe odaklanan, insana mizantropik bir perspektifle yaklaşan Demirkubuz'un yaklaşımını anlamak için açıklayıcı niteliktedir. İnsan ve insanın geleceği için olumsuz görüşler taşıyan ve bu görüşleri sinemasal üretime dönüştüren Demirkubuz, insana güvenmemekte ve insanın potansiyelini küçümsemektedir. Mizantropik görüşler taşıyan Demirkubuz insanlığın kat ettiği yolu görmeyi red etmekte sadece bardağın boş tarafına bakmaktadır. Bu noktada karamsar düşüncelerin yayıcısı olan yönetmeni sığ bir iyimserlik saylavı olmadığı için değil, yaşamı bütünselliği içinde anlatmadığı için eleştirmek gerekmektedir çünkü yaşam eninde sonunda karanlık ile aydınlığın diyalektiğiyle işlemektedir.

\section{Sonuç}

Demirkubuz, filmlerinde insan sosyal bir varlık olmaktan ziyade, diğer insanlar için kötülük tasarlayan bir düşmandır. Akıl, moral, dayanışma, empati, vefa, vicdan gibi insana özgü şeyler filmdeki kişilerin yabancı oldukları durumlardır. Yoz film kişileri davranışları ve içine girdikleri ruh halleriyle kendilerine veya diğer kişilere zarar verecek "amaçlar" peşinde sürüklenmektedir. Demirkubuz insanlara tiksinti ve düşmanlıkla yaklaşmaktadır. Filmlerdeki kişiler sevgisizdir, tutkuları olanlar bile sağlıksız biçimlerde hareket etmektedir. $\mathrm{Bu}$ açıdan Demirkubuz insanı alçaltır ve diplere doğru sürükler, insanın direnmesini, yücelmesini istemez ve film kişilerine el uzatmaz, onlara herhangi bir çıkış imkanı tanımaz. İnsanın yozlaşma ve çöküşe karşı yapacağı manevraları boşa çıkarır, insanın "insan" olabilmesine olanak tanımaz. Demirkubuz insanın sadece "karanlık" yönlerini öne çıkarır, insan iyi bir şey yapıyorsa çaresizliğinden ya da aptallı̆̆ındandır. Bu eksende Demirkubuz'un filmleri sinemadaki yozlaşmanın tipik örneğidir, soğuk ve umutsuzluk yüklüdür. İnsanı bataklığa mahkum etmektedir. Filmlerinde insanın ve dünyanın değişeceğine dair inancın kırıntısı yoktur. Demirkubuz'un insan kavrayışı, insanı toplum ve 
toplumsal ilişkilerden soyutlamak, insanın kişiliğini tahrip edip insanı alçaltmak, insanı en dibe sürüklemek ve oradan tekrar yükselebileceğini ima etmek üzerine kuruludur. Bu yaklaşım, boşluk duygusu yaratmaktan öte insan için tahripkar bir dekadans dişında bir yol bırakmamaktır. Toplumsal bir varlık olduğunu unutan yaşamı diyalektik ilişkiler temelinde tarihselliği içinde kavramayan bir insan bir sürüngene dönüşme riski taşır, Kafka'nın böceği gibi olur. Bu durum realitenin çarpıtılması, insanın metamorfoza uğraması ve yoz bir varlığa dönüşmesi demektir.

Demirkubuz'un mizantropik insan anlayışı yaşamı olumsuzlamaktadır. Filmlerde insan yaşamındaki dramatik çatışmalar ve çeşitli olumsuzluklar, tek yönlü ve genellikle tarihi ve toplumsal ilişkilerden soyutlanarak verilmekte insanın doğasına içkin olan kimi olumsuzluklar mutlaklaştırılarak kötülük estetize edilmektedir. Demirkubuz akla gelebilecek birçok olumsuzluğu ve insanın karanlık yönünü tek boyutlu ve indirgemeci biçimde öyküleştirerek insan realitesine dair mizantropik yaklaşımını ortaya koymaktadır. Demirkubuz filmlerinde insan, adeta alçalmak için vardır ve alçalma en diplere doğru sürekli bir akıştır.

Sinemada negatif olanı göstermek yoluyla olumlu olana işaret edilebilmektedir ancak yönetmenin seçilen konuya biçim ve içerik düzlemindeki yaklaşımı anlam üzerine belirleyici olmaktadır. Bu eksende Demirkubuz filmlerindeki mizantrop içerik, biçimi de belirlemekte bu yönüyle mizantrop bir film estetiği ortaya çıkmaktadır. Bu temelde filmler içerik ve biçim düzlemlerinde insanın düşürülmesine ve alçaltılmasına hizmet eden imajlarla örülmektedir. Bu çerçevede Demirkubuz negatif insan anlatıları ve pesimistik imajlara dayalı film estetizayonuyla mizantrop söylemi inşa eden bir auteur olmaktadır. Filmlerinde insanı sürekli alçaltan dahası insanın doğasını değişmez kötücül bir öze indirgeme çabası içinde olan Demirkubuz kimi filmlerinde göndermeler yapmaya çalıştığ1 felsefi düşünceleri de kendi mizantropik süzgecinden geçirmektedir. Kafka'nın böceğine dönüştürmeye çalıştığ1 insana ve insan realitesine tek boyutlu yaklaşan Demirkubuz, Yeraltı'nda Nietzsche'ye gönderme yapar. Muharrem'e Zerdüşt'ü okutur ancak iyinin ve kötünün ötesine geçemez, kötülükte takılıp kalır.

Sonuç olarak, yaşamı dönüştürmeyi daha iyi hale getirmeyi hedeflemeyen, bu konuda sözü olmayan, sürekli yaşamın sefaletine ve olumsuzluğuna takılıp kalan ve söz konusu edilen olumsuzlukları yaşam karşıtlığı formunda estetize eden bir sinema anlayışı insanı pesimist kılmak dışında bir amaca hizmet etmemektedir. Demirkubuz'un kahramanları üzerinden verdiği yaşam iletisi karamsarlıkla örülüdür. Yönetmen karakterleri için intihar, alçalma ve en dibe vurarak yüklerinden kurtulmak dışında bir çözüm önermemektedir. Bu doğrultuda Demirkubuz daha çok alçalmaya ve yozluğa eğilimli insanlarin anlatıcısı olmaktadır. 


\section{Kaynakça}

Aristoteles (1975). Politika (Çev. M.Tuncay). Remzi : İstanbul.

Bataille, Georges (2004). Edebiyat ve Kötülük. (Çev. A. Sönmezay). Ayrıntı : İstanbul.

Benatar, David (2018). Keşke Hiç Olmasaydık Var Olmanın Kötülüğü. (Çev.C.Ö.Özmen).

Doğu Batı : Ankara.

Buckland, Warren (2013). Sinemayı Anlamak. (Çev.T.Göbekçin). Optimist : İstanbul.

Demirkubuz, Zeki (Yönetmen). (2003) Bekleme Odası [Film] Türkiye : Mavi Film

Demirkubuz, Zeki (Yönetmen). (2015)Bulantı [Film]. Türkiye :Mavi Film

Demirkubuz, Zeki (Yönetmen). (1994)C Blok [Film]. Türkiye : Mavi Film

Demirkubuz, Zeki (Yönetmen). (2002)İtiraf [Film]. Türkiye : Mavi Film

Demirkubuz, Zeki (Yönetmen). (2006)Kader [Film]. Türkiye : Yerli Film - Mavi Film

Demirkubuz, Zeki (Yönetmen). (2009)Kıskanmak [Film]. Türkiye - Yunanistan : Mavi

Film - Inkas Film

Demirkubuz, Zeki (Yönetmen). (2016)Kor [Film]. Türkiye : Mavi Film

Demirkubuz, Zeki (Yönetmen). (1997)Masumiyet [Film]. Türkiye : Mavi Film

Demirkubuz, Zeki (Yönetmen). (1999)Üçüncü Sayfa [Film]. Türkiye : Mavi Film

Demirkubuz, Zeki (Yönetmen). (2001) Yazgı [Film]. Türkiye : Mavi Film

Demirkubuz, Zeki (Yönetmen). (2012) Yeraltı [Film]. Türkiye : Mavi Film

Freud, Sigmund (2011).Uygarlığın Huzursuzluğu. (Çev.H.Barışcan). Metis : İstanbul.

Freud, Sigmund (2001). Dostoyeuski ve Baba Katilliği (Çev.S.Hilav). (9-24). Dostoyevski, Fyodor (2001). Karamazov Kardeşler. (Çev.E.Altay). İletişim : İstanbul .

Fischer, Ernst (2012) Sanatın Gerekliliği. (Çev. C. Çapan). Sözcükler : İstanbul.

Fromm, Erich (2001). The Fear of Freedom. Routledge : UK.

Gruen, Arno (2010). Demokrasi Mücadelesi Radikalizm Şiddet ve Terör. (Çev. İ.İgan).

Çitlembik : İstanbul.

Hauser, Arnold. (1984). Sanatın Toplumsal Tarihi. (Çev. Y. Gölönü). Remzi : İstanbul

Hunt, Robert Edgar; Marland, John ; Rawle, Steven (2012). Film Dili. (Çev.S.Aytaç).

Literatür : İstanbul.

Jowett, John (2004). The Oxford Shakespeare : The Life of Timon of Athens. Oxford University Press : USA.

Kant, Immanuel (1997). Lectures on Ethics. (Çev. P. Heath). Cambridge University Press: UK.

Kaufmann, Walter (1965). Dostoyeðski'den Sartre'a Varoluşçuluk (Çev.A.Göktürk). De : İstanbul.

Lukacs, György (1975). Çağdaş Gerçekçiliğin Anlamı (Çev. C. Çapan). Payel : İstanbul.

Marx, Karl ; Engels, Friedrich (2013). Alman İdeolojisi. (Çev. T.Ok ve O. Geridönmez). Evrensel : İstanbul.

Nietzsche, Friedrich (2008). Deccal Hiristiyanlı̆̆a Lanet. (Çev.O .Aruoba). İthaki :İstanbul. 
Nietzsche, Friedrich (2016). İyinin ve Kötünün Ötesinde - Gelecekteki Bir Felsefeye Giriş (Çev. M. Tüzel). Türkiye İş Bankası : İstanbul.

Nietzsche, Friedrich (2014).Tan Kızıllığı Ahlaksal Önyargılar Üzerine Düşünceler. (Çev. H. Salihoğlu ve Ü. Özdağ). İmge : Ankara.

Pamuk, Orhan (2007). Önsöz : Aşağılanmanın Zevkleri. (5-13). Dostoyevski, Fyodor (2007). Yeraltından Notlar. (Çev.M.Özgül). İletişim : İstanbul.

Plato (2011). Meno and Phaedo. (Çev. A.Long). Cambridge University Press : UK.

Rousseau, Jean Jacques (2007). Bilimler ve Sanatlar Üstüne Söylev. (Çev. S.Eyüboğlu). Türkiye İş Bankası : İstanbul.

Oranl1, İmge (2017). Kötülük. Cogito Say1 86 : Kötülük -2017 (26-30). Cogito : YKY

Öztürk, Semire Ruken (2006). Kader : Zeki Demirkubuz. Dost: Ankara.

Pay, Ayşe; Afat, Ebru (2009) Zeki Demirkubuz: "Dostoyevski Olmasaydl, Edebiyat Olmasaydr

Sinemacı Olmazdım". Pay, A. (Ed.). Yönetmen Sineması : Zeki Demirkubuz. Küre : İstanbul.

Shaff, Adam; Gaidenko, Pyama (1966). Marxizm Varoluşçuluk ve Birey. (Çev. E Dinçer). İstanbul :De

Spirkin, Aleksandr (2016). Felsefenin Temel İlkeleri. (Çev.E.Kıroğlu). Yazılama : İstanbul.

Suçkov, Boris (2009). Gerçekçiliğin Tarihi. (Çev. A. Çalışlar). Doruk : İstanbul.

Ziss, Avner (2016). Estetik - Gerçekliği Sanatsal Özümsemenin Bilimi. (Çev. Y. Şahan). Hayalperest İstanbul 